\title{
Selective depletion and activation of CD8+ lymphocytes from peripheral blood of patients with polymyalgia rheumatica and giant cell arteritis
}

\author{
B DASGUPTA,${ }^{1}$ O DUKE,${ }^{1}$ A M TIMMS,${ }^{2}$ C PITZALIS, ${ }^{1}$ AND \\ G S PANAYI *
}

From the ${ }^{1}$ Rheumatology Unit, United Medical and Dental Schools, Guy's Hospital, London and ${ }^{2}$ the Department of Immunology, Royal Free Hospital, London

SUMMARY A prospective study of 33 patients with polymyalgia rheumatica/giant cell arteritis (PMR/GCA) was undertaken, firstly, to monitor sequentially peripheral blood CD8+ lymphocyte levels and, secondly, to assess the expression of activation markers on T lymphocyte subsets. The results indicated that there was a significant decrease in absolute numbers and relative percentages of $\mathrm{CD} 8+\mathrm{T}$ lymphocytes, which returned to normal ranges after approximately 24 months' treatment, and that there was an increased percentage of CD8+ lymphocytes in PMR/GCA which express HLA class II antigens.

Key words: immunofluorescence, $\mathrm{T}$ cell subsets, disease activity.

Polymyalgia rheumatica and giant cell arteritis (PMR/GCA) are diseases of unknown aetiology affecting elderly members of the population which, if inadequately treated, have a high morbidity. The sudden onset, eventual resolution in most cases, and association with HLA-DR4 ${ }^{1}$ suggest that they may have an infective aetiology or be the consequence of immune dysregulation.

Previous studies have shown that serum immunoglobulins are only occasionally raised,$^{23}$ there is no complement activation, and immune complexes are an occasional feature. ${ }^{4}$ Immunohistological analysis of the temporal artery in giant cell arteritis has shown an accumulation of CD4+ helper/inducer T lymphocytes. ${ }^{5}$ Recently, we found IgM antibodies to intermediate filaments in $68 \%$ of PMR/GCA sera. ${ }^{3}$ In the peripheral blood there is a decrease in the absolute numbers and relative proportions of CD8+ suppressor/cytotoxic T cells. ${ }^{6} 7$

Accepted for publication 11 August 1988.

Correspondence to Professor G S Panayi, Rheumatology Unit, United Medical and Dental Schools, Guy's Hospital, London SE1 9RT.

${ }^{*}$ On behalf of the polymyalgia rheumatica/giant cell arteritis study group. Other members of the group were Drs B A Latham and L Fernandes, Royal Sussex County Hospital, Brighton, West Sussex; Dr A B Myles, St Peter's Hospital, Chertsey; Drs R Grahame and T Gibson, Shepherd's House, Guy's Hospital; and Dr D G Macfarlane, Lewisham Hospital, London.
We undertook a prospective study of patients with PMR/GCA, firstly, to monitor sequentially peripheral blood CD8+ lymphocyte levels and, secondly, to assess the expression of activation markers (HLA class II antigens and interleukin 2 receptor) on $\mathrm{T}$ lymphocyte subsets. Our results indicate that there is a profound decrease in absolute numbers of $\mathrm{CD} 8+\mathrm{T}$ lymphocytes, which return to the normal range after approximately 24 months' treatment and that most CD8+ lymphocytes express class II antigens.

\section{Patients and methods}

PATIENTS AND CONTROLS

Thirty three patients were investigated. Blood samples were taken sequentially from the onset of disease (and before treatment with corticosteroids) and subsequently every three months up to 24 months. The diagnosis of polymyalgia rheumatica was based on myalgias involving shoulder and pelvic girdle muscle together with morning stiffness and an acute phase reaction (raised $\mathrm{C}$ reactive protein and erythrocyte sedimentation rate). Patients with giant cell arteritis were included after a positive temporal artery biopsy. All patients showed rapid and lasting remission of symptoms with corticosteroid treatment (10-40 mg). The seven patients tested at 24 months 
were in remission and not receiving steroids. Other diseases which could explain the symptomatologyfor example, rheumatoid arthritis, were excluded by clinical examination and appropriate investigation.

Twenty age and sex matched controls were selected from the rheumatology clinic at Guy's Hospital. All had non-inflammatory conditions such as osteoarthritis and mechanical back pain with no history of infection or neoplastic disease and with a normal erythrocyte sedimentation rate.

\section{CELL SEPARATION}

Whole blood cell counts and differential counts were performed on each sample to estimate absolute numbers of lymphocytes.

Mononuclear cells were obtained from heparinised whole blood samples by standard Ficoll-Hypaque density gradient centrifugation. ${ }^{8}$ The isolated mononuclear cells were washed twice in a large volume of RPMI 1640 medium containing $10 \%$ fetal calf serum and adjusted to a concentration of $1 \times 10^{6} \mathrm{cells} / \mathrm{ml}$ for immunofluorescent staining.

\section{M M UN OF L U ORES CEN CE}

Table 1 lists the monoclonal antibodies used in this study. Cell pellets $\left(1 \times 10^{6}\right.$ cells $)$ were labelled, firstly, with unconjugated monoclonal antibodies RFDR2 and anti-Tac, 2H4, and UCHL1 and, secondly, with fluorescein isothiocyanate conjugated polyclonal goat antimouse immunoglobulin antibody (Table 1). The cells were then incubated with normal mouse serum to block any free non-specific binding sites on the previous antibodies. Finally, the cells were labelled with a directly phycoerythrin

Table 1 Monoclonal antibodies, and their specificities and source

\begin{tabular}{|c|c|c|c|}
\hline $\begin{array}{l}\text { Monoclonal } \\
\text { antibody }\end{array}$ & $\begin{array}{l}C D \\
\text { specificity }\end{array}$ & Cell type & Source \\
\hline Leu $2 a$ & CD8 & $\begin{array}{c}\text { Suppressor/ } \\
\text { cytotoxic } \\
\text { helper } \\
\text { T cells }\end{array}$ & Becton Dickinson \\
\hline Leu 3a & CD4 & $\begin{array}{l}\text { Helper } \\
\text { T cells }\end{array}$ & Becton Dickinson \\
\hline RFDR2 & HLA-DR & $\begin{array}{l}\text { Activated } \\
\text { T cells, } \\
\text { monocytes, } \\
\text { B cells }\end{array}$ & Royal Free Hospital \\
\hline $\begin{array}{l}\text { Anti-Tac } \\
\text { (interleukin } \\
2 \text { receptor) }\end{array}$ & $\mathrm{CD} 25$ & $\begin{array}{l}\text { Activated } \\
T \text { cells }\end{array}$ & Dr T Waldmann \\
\hline $2 \mathrm{H} 4(\mathrm{SN} / 30)$ & CD45R & $\begin{array}{l}\text { Suppressor/ } \\
\text { inducer } \\
\text { T cells }\end{array}$ & Royal Free Hospital \\
\hline UCHL1 & CDw29 & $\begin{array}{l}\text { Helper/ } \\
\text { inducer } \\
\mathrm{T} \text { cells }\end{array}$ & $\begin{array}{l}\text { Dr P L C Beverley, } \\
\text { University } \\
\text { College Hospital }\end{array}$ \\
\hline
\end{tabular}

conjugated monoclonal antibody (Leu $2 \mathrm{a}$ and $\frac{\mathrm{C}}{\mathrm{S}}$. Leu 3a). The samples were washed twice after each: step and finally fixed in $1 \%$ paraformaldehyde in phosphate buffered saline and stored at $4^{\circ} \mathrm{C}$ untilo flow cytometric analysis. All reagents were titrated듬 before use, and optimal concentrations were $\overline{\frac{\omega}{2}}$ employed in all assays. Single colour immunofluor- $\mathbb{\Phi}$ escence was also performed with the phycoerythrin conjugated monoclonal antibodies.

Flow cytometry was performed with a Coulter. EPICS V machine. A laser of $488 \mathrm{~nm}$ wavelength $\overrightarrow{\vec{\omega}}$ and $200 \mathrm{~mW}$ output was used to excite fluorescence. $\omega$ Dead cells, platelets, and debris were excluded from analysis by setting an appropriate threshold on the? forward angle scatter. The cells to be analysed wereco gated using forward angle light scatter in conjunction with the phycoerythrin labelled $\mathrm{T}$ cell marker. The intensity of fluorescein isothiocyanate labelled anti-o body on these cells was measured, and the percentage with positive fluorescence was calculated as the percentage between channel 25 and channel 255 .

AUTOLOGOUS AND ALLOGENEIC MIXED

LYMPHOCYTE REACTIONS

Mononuclear cells from nine patients and nine controls were separated into $\mathrm{T}$ and non- $\mathrm{T}$ cells by using 2-aminoethylisothiouronium treated sheep redo응 blood cells as previously described ${ }^{8}$ The non-T cellso were irradiated with $30 \mathrm{~Gy}$ and then mixed with the $\mathbb{Q}^{\mathbb{D}}$ $T$ cells at 1:1 ratio and set out at a concentration of $\overrightarrow{\vec{A}}$ $1 \times 10^{6} / \mathrm{ml}$ in round bottom wells. The cells were 3 cultured in a $5 \% \quad \mathrm{CO}_{2}$ incubator at $37^{\circ} \mathrm{C}$ and harvested after 168 hours with a semiautomatic harvester. During the final 18 hours of culture $7 \cdot 4 \mathrm{kBq}\left[{ }^{3} \mathrm{H}\right]$ thymidine $(185 \mathrm{MBq} / \mathrm{mmol}$ ) (Amershamō International plc) was added to each well. The thymidine incorporation was measured in a liquid. scintillation counter (LKB Wallac). The results wereô expressed as disintegrations per minute (dpm).

Irradiated mononuclear cells $(30 \mathrm{~Gy})$ from two윽 individuals were used instead of the non-T cell in the $>$ allogeneic mixed lymphocyte reaction. The rest of the procedure was as in the autologous mixedn lymphocyte reaction.

\section{STATISTICAL METHODS}

Student's $t$ test was used to determine statisticalo significance. Results are expressed as mean (SE).

\section{Results}

SINGLE COLOUR ANALYSIS OF T CELL S U B SET S

Table 2 and Fig. 1 present data on $T$ cell subsets $\stackrel{\Omega}{\mathscr{Q}}$ reactive with Leu 2a (suppressor/cytotoxic) ando Leu 3a (helper/inducer). There was a significant 


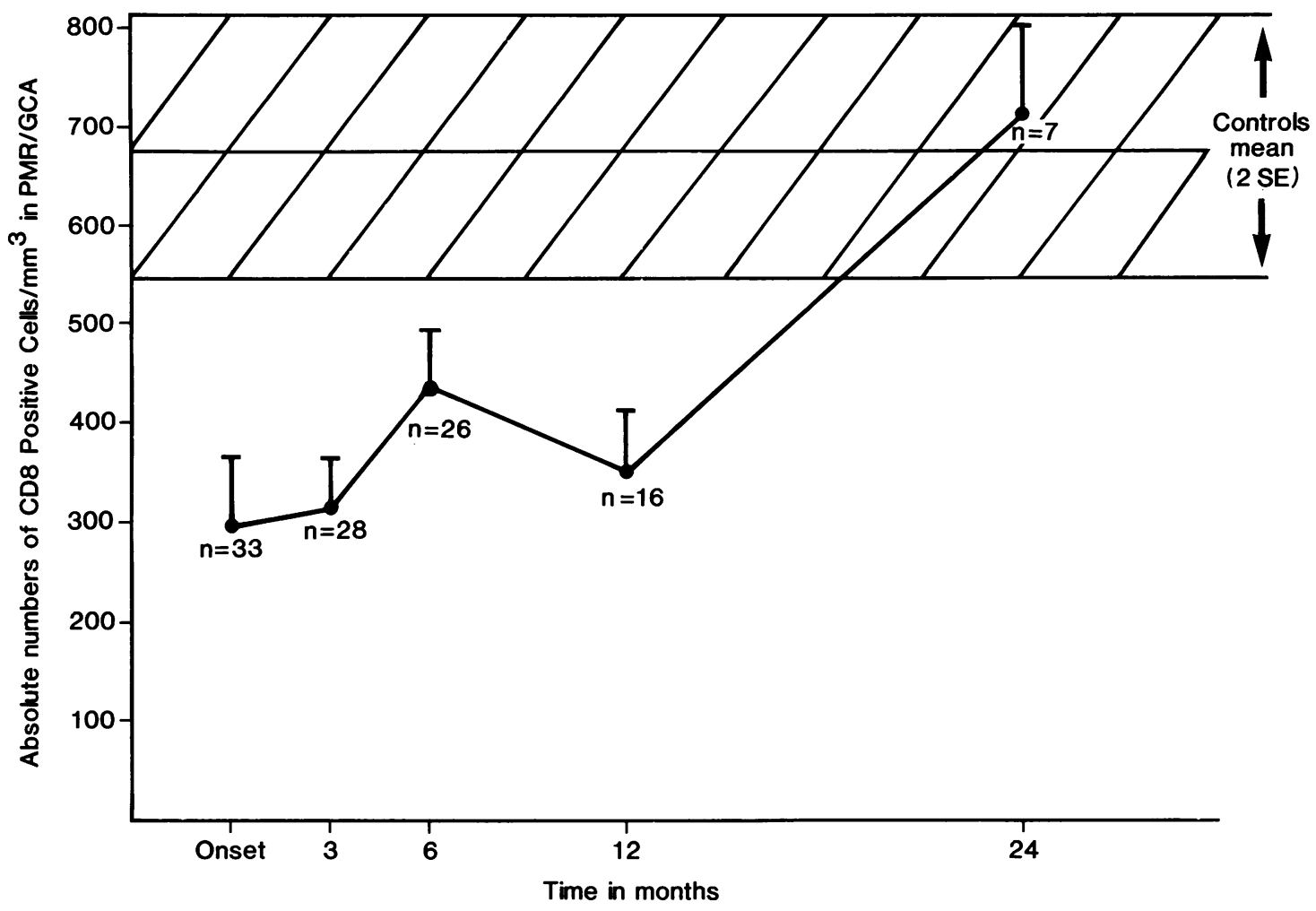

Fig. 1 Absolute numbers of CD8+ lymphocytes in polymyalgia rheumatica/giant cell arteritis $(P M R / G C A)$ from onset of disease up to 24 months of follow up.

decrease in absolute numbers of Leu $2 a+$ cells in patients with PMR/GCA at onset and up to 12 months compared with those in controls. Only at 24 months or more did the absolute numbers of

Table 2 Absolute numbers (SE) per $\mathrm{mm}^{3}$ and relative percentages of $T$ cell subsets

\begin{tabular}{|c|c|c|c|c|}
\hline \multirow[t]{2}{*}{ Group } & \multicolumn{2}{|l|}{ CD8 T cells } & \multicolumn{2}{|l|}{ CD4 T cells } \\
\hline & No & $\%$ & No & $\%$ \\
\hline \multirow{2}{*}{\multicolumn{5}{|c|}{$\begin{array}{l}\text { Controls } \\
(n=20) \\
\text { PMR/GCA }+ \text { : }\end{array}$}} \\
\hline & & & & \\
\hline $\begin{array}{c}(n=33) \\
\text { At } 3 \text { months }\end{array}$ & $299(61 \cdot 9)^{*}$ & $11 \cdot 3$ & $1570(77 \cdot 9)$ & $59 \cdot 3$ \\
\hline & $315(50 \cdot 2)^{*}$ & $10 \cdot 9$ & $1639(127 \cdot 3)$ & $56 \cdot 5$ \\
\hline $\begin{array}{l}(n=26) \\
\text { At } 12 \text { months }\end{array}$ & $426.8(60 \cdot 3)^{*}$ & $14 \cdot 6$ & $1561(155 \cdot 3)$ & $53 \cdot 8$ \\
\hline $\begin{array}{l}(n=16) \\
\text { At } 24 \text { months }\end{array}$ & $341(62 \cdot 0)^{*}$ & $12 \cdot 1$ & $1473(176 \cdot 0)$ & $52 \cdot 6$ \\
\hline$(n=7)$ & $718(137 \cdot 6)$ & $28 \cdot 4$ & $1089(162 \cdot 2)$ & $43 \cdot 2$ \\
\hline
\end{tabular}

${ }^{*} \mathrm{p}<0.005$.

†PMR/GCA = polymyalgia rheumatica/giant cell arteritis.
Leu $2 \mathrm{a}+$ cells rise to the range found in controls (Fig. 1). There was no difference between numbers of Leu $3 a+$ cells in controls and patients with PMR/GCA at any stage of their disease.

TWO COLOUR ANALYSIS OF T CELL SUBSETS There was a significant increase in the relative percentages of Leu $2 a+D R+$ cells in the PMR/GCA group as compared with controls. This increase persisted despite 12 months' treatment (Table 3). The percentage of Leu 3a+ DR + cells in PMR/GCA remained within the control range at every stage of the disease. There was no difference in numbers of interleukin 2 receptor positive cells in either the Leu $2 \mathrm{a}+$ or Leu $3 \mathrm{a}+$ population between patients and controls (data not shown). There was also no difference in percentages of $2 \mathrm{H} 4+$ and UCHL1+ cells in either Leu $2 \mathrm{a}+$ or Leu $3 \mathrm{a}+$ populations between patients and controls (data not shown).

AUTOLOGOUS AND ALLOGENEIC MIXED LYMPHOCYTE REACTIONS

There was no significant difference in thymidine incorporation between the patient and control 
Table 3 Two colour analysis of $T$ cell subsets for $C D 8+$ or $C D 4+T$ cells and simultaneous expression of $H L A-D R$. Values are mean percentage (SE)

\begin{tabular}{lll}
\hline Group & $\begin{array}{l}C D 8 \text { DR+ } \\
(\%)\end{array}$ & $\begin{array}{l}\text { CD4 DR+ } \\
(\%)\end{array}$ \\
\hline Controls $(\mathrm{n}=15)$ & $10 \cdot 6(1 \cdot 1)$ & $7 \cdot 0(0 \cdot 8)$ \\
PMR/GCA + : & & \\
At onset $(\mathrm{n}=22)$ & $20 \cdot 3(3 \cdot 3)^{*}$ & $9 \cdot 9(2 \cdot 4)$ \\
At 6 months $(\mathrm{n}=20)$ & $27 \cdot 3(3 \cdot 4)^{*}$ & $7 \cdot 4(2 \cdot 6)$ \\
At $>12$ months $(\mathrm{n}=12)$ & $21 \cdot 5(2 \cdot 1)^{*}$ & $7 \cdot 2(1 \cdot 1)$ \\
\hline
\end{tabular}

${ }^{*} \mathrm{p}<0.005$.

†PMR/GCA = polymyalgia rheumatica/giant cell arteritis.

groups in the autologous mixed lymphocyte reaction (mean (SE): (25 341 (5746) v 23324 (3690) dpm)) and the allogeneic mixed lymphocyte reaction (20 100 (3496) v 24873 (3972) dpm).

\section{Discussion}

Our study shows that there is a profound decrease in absolute numbers and relative percentages of Leu 2a+ (CD8 + suppressor/cytotoxic cells) in patients with PMR/GCA. Two previous studies have reported a decrease of CD8+ cells in PMR/ GCA. ${ }^{6}{ }^{7}$ Their conclusions as to the relation between the $\mathrm{CD} 8+$ decrease and disease activity, duration, or steroid treatment were conflicting, however. Our results show that this profound and selective CD8+ $T$ lymphopenia seen at the onset of disease persists for up to one year despite successful steroid treatment, with remission of clinical disease and normalisation of laboratory markers - that is the erythrocyte sedimentation rate and $\mathrm{C}$ reactive protein. Only by 24 months do the numbers of $\mathrm{CD} 8+$ cells return to within the normal control range. Thus despite rapid control of disease manifestations by steroid treatment the underlying immunoregulatory deficit persists for a much longer time. This may have its clinical correlate in observations of relapse of apparently quiescent disease after steroid withdrawal even after one to two years of treatment. Thus monitoring of levels of CD8 + cells may prove useful in the regular follow up of patients with PMR/GCA.

It is interesting that despite the severe decrease in CD8 + cell numbers there are no manifestations of decreased suppressor activity. Serum immunoglobulins are normal, and the paucity of autoantibodies (except antibodies to intermediate fillaments) suggests that there is no $B$ cell overactivity. ${ }^{34}$ One study of concanavalin A inducible suppressor function in PMR/GCA reported it to be normal. ${ }^{6}$ These results can be explained by the normal distribution of the suppressor inducer cells demon strated in this study - so that despite the decreased? number of $\mathrm{CD} 8+$ cells these can be properlys activated to a normal function by normal CD4to 2H4+ lymphocytes. Our study of the autologous and allogeneic mixed lymphocyte reactions in PMR GCA has found both to be similar to those of normal age and sex matched controls. Again this iš predictable in view of normal $\mathrm{CD} 4+2 \mathrm{H} 4+$ celf numbers, which are the main responders in the autologous mixed lymphocyte reaction. ${ }^{9}$

The cause of the CD8+ lymphopenia is unclear. If may reflect $(a)$ antibody mediated destruction andu (b) an abnormality intrinsic to the CD8+ cells? Experiments are currently in progress in our laborapo tory to elucidate further the cause of the CD8 decrease. Mechanisms involving antibody mediate cytotoxicity have recently been described as being responsible for the decrease in CD4+ T cells in the peripheral blood of patients with AIDS. ${ }^{10}$ Although these cells are decreased in absolute numbers, a large proportion are activated as evident by their expres sion of HLA-DR antigen. It is possible that thes $5_{0}^{\circ}$ activated cells are responding to the antigen that is inciting the disease process and therefore involved in the pathogenesis of PMR/GCA. It is interesting to note that another disease which is characterise of by severe CD8+ cell $\mathrm{T}$ cell lymphopenia anc increased numbers of activated cells is Kawasaki' disease. Recently there have been reports of at possible retroviral aetiology for this disease. ${ }^{11} 12$

We suggest, therefore, that the sequential monitoring of CD8 $+\mathrm{T}$ cell subsets in PMR/GCA carb contribute to the clinical management of the disease as well as enhance our understanding of the aetio pathogenesis of this mysterious disease complex.

We would like to thank the Arthritis Research Council fo supporting this work. We would also like to thank Mrs Pattie Powell for typing the manuscript.

\section{References}

1 Armstrong R D, Behn A, Myles A, Panayi G S, Welsh K I." Histocompatibility antigens in polymyalgia rheumatica and giant cell arteritis. J Rheumatol 1983; 10: 659-61.

2 Malmvale B E, Bengtsson B A, Kayser B, Nilsson L A, Alestig K. Serum levels of immunoglobulins and complement in giant celk arteritis. JAMA 1976; 236: 1876-8.

3 Dasgupta B, Duke O, Kyle V, Macfarlane D G, Hazleman B L, Panayi G S. Antibodies to intermediate filaments in polymyalgia rheumatica and giant cell arteritis: a sequential study. Ann Rheum Dis 1987; 46: 746-9.

4 Espinoza L R, Bridgeford P, Lowenstein M. Polymyalgia rheumatica and giant cell arteritis circulating immune complexes. J Rheumatol 1982; 9: 556-60.

5 Banks P M, Cohen M D, Ginsburg W W, Hunder G G. ̊ Immunohistological and cytochemical studies of temporal arter- $\bar{\gamma}$ itis. Arthritis Rheum 1983; 26: 1201-7. 
6 Benlarache C, Segond P, Anguier L, Bouret J P. Decrease of OKT8 positive $\mathrm{T}$ cell subset in polymyalgia rheumatica. Arthritis Rheum 1983; 26: 1472-80.

7 Elling H, Elling P. Decreased level of suppressor/cytotoxic $T$ cell (OKT8) in polymyalgia rheumatica and giant cell arteritis: relation to disease activity. $J$ Rheumatol 1985; 12: 306-9.

8 Kingsley G, Pitzalis C, Panayi G S. Abnormal lymphocyte reactivity to self-major histocompatibility antigens in rheumatoid arthritis. J Rheumatol 1987; 14: 667-73.

9 Morimoto C, Letvin N L, Diastaso J A, Aldrich W R,
Schlossman S F. The isolation and characterisation of the human suppressor inducer $T$ cell subset. $J$ Immunol 1985; 134: 1508-15.

10 Stricker R B, McHugh T M, Moody D J, et al. An AIDS related cytotoxic autoantibody reacts with a specific antigen on stimulated CD4+ T cells. Nature 1987; 327: 710-3.

11 Shulman S T, Rowley A H. Does Kawasaki disease have a retroviral aetiology? Lancet 1986; ii: 545-6.

12 Burns J C, Geha R S, Schneeberger E E, et al. Polymerase activity in lymphocyte culture supernatants from patients with Kawasaki disease. Nature 1986; 323: 814-6. 


\section{Notes and news}

\section{World Confederation for Physical Therapy}

The 11th international congress of the World Confederation for Physical Therapy will be held at the Barbican Centre, London, from 28 July to 2 August 1991. Information from Conference Associates WCPT, Congress House, 55 New Cavendish Street, London W1M 7RE. Tel: 01 486 0531. Telex: 934346 CONFAS G. Fax: 019357559.

\section{Symposium on back pain}

The American Back Society autumn symposium on back pain will be held from 30 November to 3 December 1989 in Las Vegas, Nevada, and the course chairman will be Vert Mooney, MD; 18" hours CME credit. Further information from the American Back Society, 2647 East 14th Street, Suite 401, Oakland, CA 94601 (415) 536 9929, USA.

\section{Free radicals and the immune response}

The VIIth annual inflammation meeting entitled 'Free radicals and the immune response' will be held on the 7 and 8 September 1989 at the Postgraduate Medical Centre, The Queen Elizabeth Medical Centre, Edgbaston, Birmingham. Further information from The Secretariat, Department of Rheumatology, The Medical School, University of Birmingham, Birmingham B15 2TJ. Tel: 021414 6778. Fax: 0214144036.

\section{Osteoporosis and bone mineral measurement}

The second conference on osteoporosis and bone mineral measurement will be held from 25 to 27 June 1990 at the Guildhall, Bath, United Kingdom under the auspices of the Royal National Hospital for Rheumatic Diseases, Bath, and the National Osteoporosis Society. For further information please contact either Dr E F J Ring, Department of Clinical Measurement, Royal National Hospital for Rheumatic Diseases, Bath, UK. Tel: (0) 225 65941, or the National Osteoporosis Society, Barton Meade House, PO Box 10, Radstock, Bath BA3 3YB.

\section{Carol-Nachman award for rheumatology}

This international prize will be awarded annually for research of merit in the field of rheumatology and it is endowed with DM 75000 . Work may be submitted up to 31 July 1989, and further information is available from Professor Dr med D Maas, Rheumaklinik I, Langgasse 38-40, D-6200, Wiesbaden/FRG.

Correction: Selective depletion and activation of CD8+ lymphocytes from peripheral blood of patients with polymyalgia rheumatica and giant cell arteritis. In the paper by Dr B Dasgupta et al (Ann Rheum Dis 1989; 48: 307-11) an authors' error occurred in Table 1 . The antigenic specificity of the UCHL1 antibody should have read as CD45R-0 instead of CDw29 and in the revised CD nomenclature the antigenic specificity of the $2 \mathrm{H} 4$ antibody should have read as CD45R-A. 